\title{
Socioeconomic and country variations in cross-border cigarette purchasing as tobacco tax avoidance strategy. Findings from the ITC Europe Surveys
}

\author{
Gera E Nagelhout, ${ }^{1,2}$ Bas van den Putte, ${ }_{1}^{3}$ Shane Allwright, ${ }^{4}$ Ute Mons, ${ }^{5}$ \\ Ann McNeill, ${ }^{6}$ Romain Guignard, ${ }^{7}$ François Beck, ${ }^{7,8}$ Mohammad Siahpush ${ }^{9}$ \\ Luk Joossens, ${ }^{10}$ Geoffrey T Fong, ${ }^{11,12}$ Hein de Vries, ${ }^{1}$ Marc C Willemsen ${ }^{1,2}$
}

For numbered affiliations see end of article.

\section{Correspondence to Gera Nagelhout, STIVORO Dutch Expert Centre on Tobacco Control, PO Box 16070, The Hague 2500 BB, The Netherlands; gnagelhout@stivoro.nl}

Received 15 October 2012 Accepted 11 April 2013 Published Online First 3 May 2013
To cite: Nagelhout $G E$, van den Putte B, Allwright $S$,

et al. Tob Control 2014;23: i30-i38.

\section{ABSTRACT \\ Background Legal tobacco tax avoidance strategies} such as cross-border cigarette purchasing may attenuate the impact of tax increases on tobacco consumption. Little is known about socioeconomic and country variations in cross-border purchasing.

Objective To describe socioeconomic and country variations in cross-border cigarette purchasing in six European countries.

Methods Cross-sectional data from adult smokers $(n=7873$ ) from the International Tobacco Control (ITC) Surveys in France (2006/2007), Germany (2007), Ireland (2006), The Netherlands (2008), Scotland (2006) and the rest of the UK (2007/2008) were used. Respondents were asked whether they had bought cigarettes outside their country in the last 6 months and how often. Findings In French and German provinces/states bordering countries with lower cigarette prices, $24 \%$ and $13 \%$ of smokers, respectively, reported purchasing cigarettes frequently outside their country. In non-border regions of France and Germany, and in Ireland, Scotland, the rest of the UK and The Netherlands, frequent purchasing of cigarettes outside the country was reported by $2-7 \%$ of smokers. Smokers with higher levels of education or income, younger smokers, daily smokers, heavier smokers and smokers not planning to quit smoking were more likely to purchase cigarettes outside their country.

Conclusions Cross-border cigarette purchasing is more common in European regions bordering countries with lower cigarette prices and is more often reported by smokers with higher education and income. Increasing taxes in countries with lower cigarette prices, and reducing the number of cigarettes that can be legally imported across borders could help to avoid cross-border purchasing.

\section{INTRODUCTION}

Tobacco tax increases have been demonstrated to be the single most effective and cost-effective intervention for reducing tobacco use. ${ }^{12}$ However, not all smokers react to tax increases by quitting smoking because they have several other options. ${ }^{3}$ Smokers may not let the tax increase influence their smoking behaviour, they may cut back on the number of cigarettes smoked, or switch to discount brands or rolling tobacco. Moreover, they may use legal tax avoidance strategies, such as internet shopping and cross-border shopping or illegal tax evasion strategies, such as smuggling or buying counterfeit tobacco. ${ }^{3}$ Tax avoidance and evasion strategies may attenuate the impact of tax increases on tobacco consumption ${ }^{4}$ (although some have a different view ${ }^{5}$ ) and reduce tax revenue, and also may undermine confidence in law enforcement.

The European Union (EU) has open borders between EU countries and tax and price rates of tobacco differ substantially between EU countries. ${ }^{16-8}$ In 2009, cigarette prices varied sixfold and affordability fourfold, between EU countries. ${ }^{8}$ Europe's open borders might tempt smokers from countries with high cigarette prices to use crossborder cigarette purchasing as a tobacco tax avoidance strategy. According to the EU regulations, there are no limits on how much tobacco private persons can import from other EU countries, as long as the products are purchased for personal use and transported by the smoker himself. Although EU countries may set guide levels (ie, upper limits) on what may be considered personal consumption, the guide level may not be less than 800 cigarettes or $1 \mathrm{~kg}$ of rolling tobacco. Limits for importing tobacco from non-EU countries, however, vary from 40 to 200 cigarettes and 50 to $250 \mathrm{~g}$ of rolling tobacco.

Previous research showed that cross-border cigarette purchasing was not a problem in Europe in the 1990s. ${ }^{6}$ Not many travellers bought tobacco abroad, and those who did bought only small quantities. ${ }^{6}$ This could have changed in the 21 st century, because the number of EU countries has grown from 12 countries in 1995 to 27 countries in 2007. Also, the price differentials for the same cigarette brand increased from $240 \%$ in $1995^{6}$ to $590 \%$ in $2007 .^{7}$ Recent studies showed that France has significant amounts of cross-border purchasing, ${ }^{9-11}$ mainly from Spain, Belgium and Luxembourg. A European Commission survey showed that in 2008, cross-border purchasing was highest in Ireland, the UK and France. ${ }^{12}$ However, this study asked about purchasing cigarettes at their last trip in another EU country and did not take into account how often people crossed the border and purchased cigarettes. People may buy cigarettes when they happen to be in a country for a different reason (eg, vacation or business) or they may purposely cross the border to buy cheaper cigarettes. Purposely crossing the border for cheaper cigarettes might be a frequent activity primarily among smokers living close to the border of a country with lower cigarette prices. ${ }^{13}$ A study in Germany showed that cross-border cigarette purchasing was 
strongly associated with living near countries with lower cigarette prices, that is, Luxembourg, Poland and the Czech Republic. ${ }^{14}$

In Europe, smoking is more common among lower than higher socioeconomic status (SES) groups. ${ }^{12}$ While tobacco tax increases are found to stimulate tobacco use reduction especially among smokers of lower SES, ${ }^{14}$ there may also be socioeconomic differences in tax avoidance. Knowledge about SES differences in tax avoidance is important because it may provide information about possible effects of policies that are designed to reduce tax avoidance and whether these are beneficial or detrimental for low SES smokers. Not much is known about this because few studies have used individual-level data to examine tax avoidance strategies. Three studies that used individual-level data and examined socioeconomic differences did not distinguish between cross-border cigarette shopping and other tax avoidance behaviours. ${ }^{15-17}$ The few studies that have examined individual differences in cross-border shopping had mixed results. ${ }^{12} 141819$ A study from Germany ${ }^{14}$ and an EU-wide study ${ }^{12}$ found no educational differences. However, recent studies from the USA found that smokers with higher education and income were more likely to purchase cigarettes in another state. ${ }^{18} 19$

In this study, we describe socioeconomic and country variations in cross-border cigarette purchasing in France, Germany, the Republic of Ireland, The Netherlands and the UK. The UK and Ireland are the two European countries with the highest cigarette prices. ${ }^{7}$ Cigarette prices in France and Germany are somewhat lower, while The Netherlands has the lowest cigarette prices of the countries in this study. France and Germany have large borders with countries that have considerably lower cigarette prices. Therefore, we expect cross-border purchasing to be most prevalent in France and Germany.

The following research questions were examined in this study: (1) are there country variations in the prevalence of cross-border cigarette purchasing? (2) are there socioeconomic variations in the prevalence of cross-border cigarette purchasing?

\section{METHODS}

\section{Sample}

Cross-sectional data from 7873 adult smokers from the International Tobacco Control (ITC) Europe Surveys in France, Germany, Ireland, The Netherlands and the UK were used. Results are reported separately for Scotland and the rest of the UK because the ITC Scotland Survey was a separate survey from the ITC UK Survey with its own representative sample of smokers from Scotland. Because the ITC Ireland Survey ended in 2006 and the ITC Netherlands Survey began in 2008, survey waves closest to 2007 were used for the study. See table 1 for fieldwork periods, sample sizes and cooperation rates for each ITC Survey.

Respondents were recruited using probability sampling methods with fixed line telephone numbers selected at random from the population of each country and were surveyed using telephone interviewing. Respondents were eligible if they had smoked at least 100 cigarettes in their lifetime and currently smoked at least once per month. The Netherlands sample differed in that most respondents were surveyed using web interviewing instead of telephone interviewing. ${ }^{21}$ The Dutch web sample was drawn from a large probability-based database with respondents who had indicated their willingness to participate in research on a regular basis. Therefore, multivariate analyses controlled for interviewing mode.

\section{Ethics}

All surveys were cleared for ethics by the Office of Research Ethics of the University of Waterloo, Canada, and also by the appropriate institutions in all participating countries.

\section{Measurements}

The questions used for the ITC Europe Surveys were all adapted from the conceptual model and questionnaire of the ITC Four Country Survey. ${ }^{22}$

Cross-border cigarette purchasing was measured by asking respondents whether they had bought cigarettes outside their country in the last 6 months. Respondents who answered in the affirmative were asked how often they had done this in the

Table 1 Fieldwork period, sample size of current smokers and cooperation rate for each International Tobacco Control (ITC) Europe Survey

\begin{tabular}{|c|c|c|c|}
\hline & Fieldwork period & Sample size & Cooperation rate $(\%)^{*}$ \\
\hline \multicolumn{4}{|l|}{ Netherlands $\dagger$} \\
\hline Telephone sample & March 2008-April 2008 & 404 & 78.1 \\
\hline Web sample & April 2008 & 1668 & 78.1 \\
\hline France $\ddagger$ & December 2006-February 2007 & 1735 & 75.3 \\
\hline Germany§ & July 2007-November 2007 & 1515 & 94.9 \\
\hline Republic of Ireland $\emptyset$ & February 2006-March 2006 & 577 & 71.9 \\
\hline Scotland** & February 2006-March 2006 & 507 & 66.7 \\
\hline UK (w/o Scotland)t† & September 2007-February 2008 & 1467 & 74.6 \\
\hline Total & & 7873 & \\
\hline \multicolumn{4}{|c|}{ 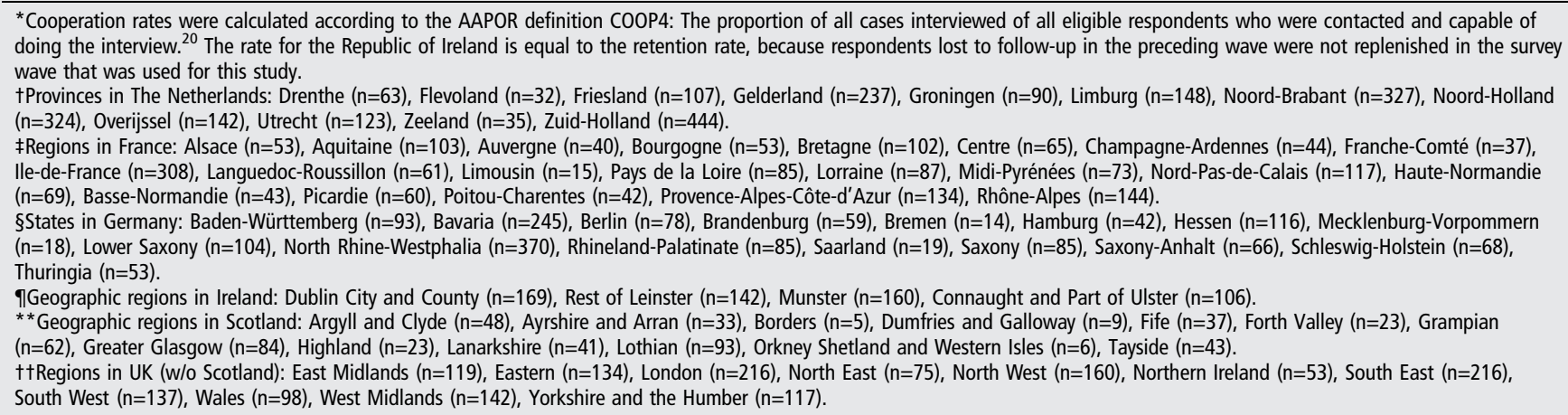 } \\
\hline
\end{tabular}


previous 6 months. Response categories were 'Only once', 'A few times', 'Many times' and 'All of the time'. A new variable with three categories was constructed for the analyses: (1) no cross-border cigarette purchasing; (2) occasional (ie, only once and a few times) and (3) frequent (ie, many times and all of the time) cross-border cigarette purchasing.

Respondents were categorised as living or not living in a province/state bordering a country that has cigarette prices at least $€ 1.00$ lower per pack. The retail price of the most popular price category cigarettes in January of the survey year was used. ${ }^{23}$ This is country-level price data, as tobacco taxation does not vary at the regional level within the included countries. The neighbouring countries of The Netherlands, Ireland and Scotland did not have cigarette prices $€ 1.00$ lower per pack in the ITC survey year that was used in this study (see figure 1). All neighbouring countries of France and some of the neighbouring countries of Germany (ie, Poland, the Czech Republic and Austria) had cigarette prices at least $€ 1.00$ lower per pack. Therefore, respondents from the French provinces Alsace, Aquitaine, Champagne-Ardennes, Franche-Comté, Languedoc-Roussillon, Lorraine, Midi-Pyrénées, Nord-Pas-de-Calais, Picardie, Provence-Alpes-Côte-d'Azur and Rhône-Alpes, and respondents from the German states of Bavaria, Brandenburg, Mecklenburg-Vorpommern, Rhineland-Palatinate, Saarland and Saxony were categorised as living in a province/state bordering a country that has cigarette prices at least $€ 1.00$ lower per pack.

Education and income were used as indicators of SES. ${ }^{24}$ Education was categorised into three levels: low (no degree, elementary school and lower secondary education), moderate (secondary vocational education and middle secondary education), and high (upper secondary education, university and postgraduation). The education levels were only partly comparable across countries because of differences in educational systems. Respondents from most countries were asked about their gross household income per month. However, respondents from Germany and France were asked about their net household

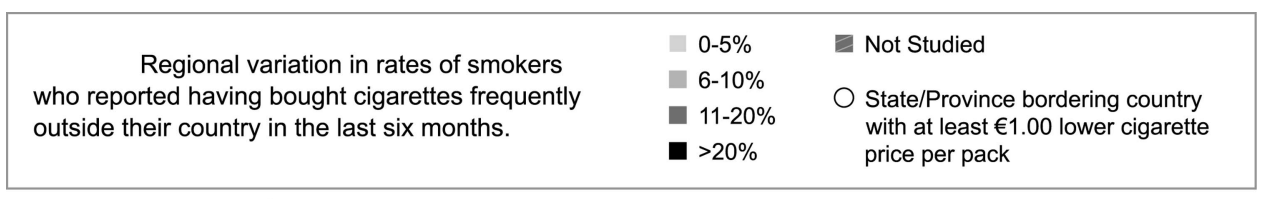

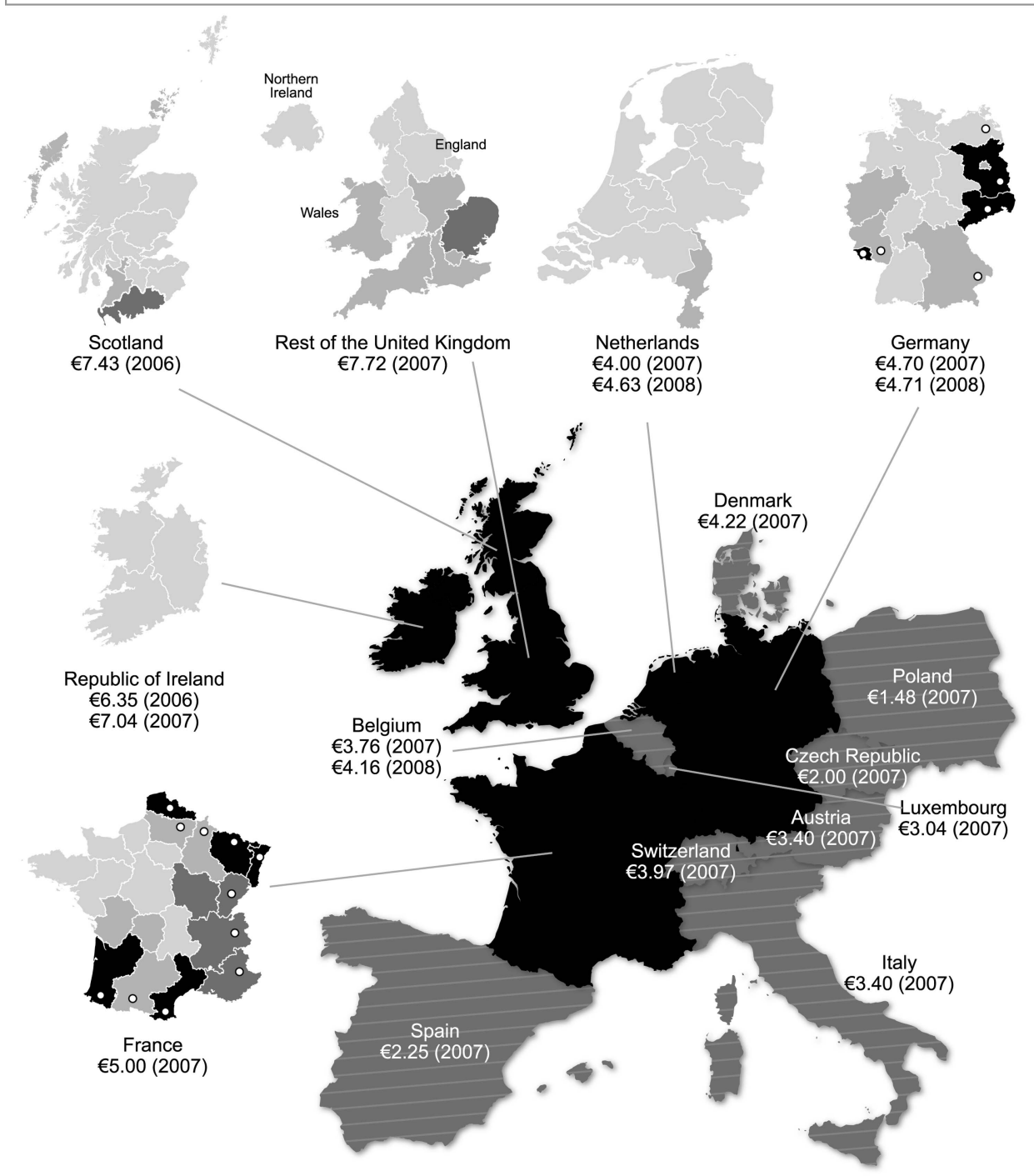

Figure 1 Regional variation in rates of smokers who reported having bought cigarettes frequently outside their country in the last 6 months. Prices in the figure are the retail prices of the most popular price category cigarettes in January of the year shown in brackets. 
income. Also, answering categories were not comparable across all countries. Therefore, we created a relative income variable that was categorised into tertiles for each country. Respondents who did not answer the income question $(n=952)$ were recorded in a separate category.

Covariates in the multivariate analyses were gender, age group (18-24, 25-39, 40-54 and 55 years and older), employment, smoking status (daily vs occasional smoker), heaviness of smoking, intention to quit (within 6 months vs not within 6 months), smoking exclusively rolling tobacco and/or manufactured cigarettes, and interviewing mode. The Heaviness of Smoking Index (HSI) was created as the sum of two categorised measures: number of cigarettes per day and time before smoking the first cigarette of the day. ${ }^{25}$ HSI values ranged from 0 to 6 with higher values indicating stronger nicotine dependence. ${ }^{25}$

\section{Analyses}

To confirm that our measure of cross-border cigarette purchasing is indicative of a tax avoidance strategy, we analysed the differences in the average of self-reported prices for a pack of cigarettes at last purchase between respondents who reported frequent, occasional and no cross-border purchasing in the last 6 months, with t tests. Country and socioeconomic variations in the prevalence of cross-border cigarette purchasing were examined with $\chi^{2}$ tests. Also, a multinomial logistic regression analysis was performed with cross-border cigarette purchasing as the dependent variable. Although the dependent variable had an ordinal distribution, we employed multinomial regression because this analysis was capable of producing estimated ORs for both occasionally and frequently purchasing cigarettes outside the country rather than not purchasing cigarettes outside the country, according to values of the independent variables. Independent variables were gender, age group, educational level, income level, employment, smoking status, heaviness of smoking, intention to quit, smoking exclusively rolling tobacco, country/region and interviewing mode.

\section{RESULTS}

\section{Sample characteristics}

Sample characteristics for each country and (border or nonborder) regions are shown in table 2 . There were significant country/region differences in all variables that were used in this study. Differences between countries were relatively large for educational level. However, it should be noted again that educational levels were only partly comparable across countries. The Netherlands had the highest percentage of smokers not willing to answer the question about their income. Unemployment among smokers was highest in Scotland. Smokers from Scotland and the rest of the UK were most often daily smokers and scored highest on the HSI. Smokers from Scotland had the highest intention to quit smoking within 6 months. Smokers from The Netherlands were more likely to report smoking exclusively rolling tobacco, while smoking factory made cigarettes exclusively or alongside rolling tobacco was reported most often by smokers from Ireland.

There were some significant differences in sample characteristics between smokers living in border and non-border provinces/states in France and Germany. Smokers from border provinces of France were less educated, had lower income levels, and were more often unemployed than smokers from non-border provinces of France. Smokers from border states of Germany were more often male, were less educated and smoked more often factory made cigarettes than smokers from non- border states. These differences may affect or be affected by the decision to purchase cigarettes across the border.

\section{Confirmation of cross-border cigarette purchasing measure}

Respondents who reported having frequently purchased cigarettes outside their country in the last 6 months paid significantly less for their cigarettes (on average $€ 4.24$ for one pack) than respondents who reported having occasionally purchased cigarettes outside their country $(€ 4.64)(t=2.57, p=0.011)$. There was no significant difference in price paid for a pack of cigarettes between respondents who reported having occasionally purchased cigarettes outside their country and respondents who reported not having purchased cigarettes outside their country in the last 6 months $(€ 4.85)(\mathrm{t}=0.93, \mathrm{p}=0.351)$.

The same pattern was found in each country except Ireland. In Ireland, smokers who frequently bought cigarettes outside their country paid significantly more for their cigarettes than other respondents. The decrease in price between smokers who frequently bought cigarettes outside their country and those who bought them occasionally was largest in France and Germany.

\section{Country variations in cross-border cigarette purchasing}

As can be seen in table 3, there were large differences in crossborder cigarette purchasing between countries and regions $\left(\chi^{2}(14)=771.59, p<0.001\right)$. Highest rates of smokers reporting frequently purchasing cigarettes outside their country in the last 6 months were found in the border regions of France (24\%) and Germany (13\%). In non-border regions of France and Germany, only 5\% reported frequent cross-border cigarette purchasing in the last 6 months. Highest rates of smokers reporting not having purchased cigarettes outside their country were found in The Netherlands (83\%), Scotland (78\%) and Ireland (74\%).

\section{Socioeconomic variations in cross-border cigarette purchasing}

Table 3 shows that there were significant variations in crossborder cigarette purchasing between educational levels $\left(\chi^{2}(4)\right.$ $=130.19, \mathrm{p}<0.001)$ and income levels $\left(\chi^{2} \quad(6)=184.88\right.$, $\mathrm{p}<0.001$ ), in particular for occasional purchasing. Of smokers with a high educational level, $31 \%$ reported occasionally buying cigarettes outside their country, and $8 \%$ reported frequently buying cigarettes outside their country in the last 6 months. For smokers with a low educational level, the percentages were $18 \%$ and $5 \%$, respectively. Of smokers with a high income level, $32 \%$ reported occasionally buying cross-border and $8 \%$ frequently. Of smokers with a low income level, 19\% reported occasionally buying cross-border and $6 \%$ frequently.

\section{Correlates of cross-border cigarette purchasing}

The multinomial logistic regression analysis in table 4 shows that occasionally buying cigarettes outside the country was more frequently reported by younger smokers, smokers with a higher education and income level, employed smokers, daily smokers, smokers who smoked factory made cigarettes, and telephone respondents. The correlates of frequently buying cigarettes outside the country were mostly comparable, with a few notable differences. Smokers who reported frequently purchasing cigarettes outside their country were more likely to be heavier smokers and were less likely to plan to quit smoking. Smoking factory made cigarettes was not associated with frequent cross-border purchasing. The strongest correlate of frequent cross-border cigarette purchasing was country and region. Respondents living in a border province of France, a border 
Table 2 Differences in demographic and smoking characteristics across country and (border or non-border) region (\%)

\begin{tabular}{|c|c|c|c|c|c|c|c|c|c|}
\hline & \multirow{2}{*}{$\begin{array}{l}\text { Netherlands } \\
(n=2072)\end{array}$} & \multicolumn{2}{|l|}{ France } & \multicolumn{2}{|l|}{ Germany } & \multirow{2}{*}{$\begin{array}{l}\text { Ireland } \\
(n=577)\end{array}$} & \multirow{2}{*}{$\begin{array}{l}\text { Scotland } \\
(n=507)\end{array}$} & \multirow{2}{*}{$\begin{array}{l}\text { UK (w/o } \\
\text { Scotland) } \\
(n=1467)\end{array}$} & \multirow{2}{*}{$\begin{array}{l}\text { Test of } \\
\text { differences } \\
\text { between country } \\
\text { region }\end{array}$} \\
\hline & & $\begin{array}{l}\text { Border } \\
\text { provinces* } \\
\text { (n=879) }\end{array}$ & $\begin{array}{l}\text { Non-border } \\
\text { provinces } \\
(\mathrm{n}=856)\end{array}$ & $\begin{array}{l}\text { Border } \\
\text { statest } \\
(n=469)\end{array}$ & $\begin{array}{l}\text { Non-border } \\
\text { states } \\
(n=1046)\end{array}$ & & & & \\
\hline \multicolumn{10}{|l|}{ Demographic characteristics } \\
\hline \multicolumn{10}{|l|}{ Gender } \\
\hline Female & 45.7 & 46.3 & 42.4 & 36.8 & 44.8 & 45.4 & 45.8 & 49.8 & $\chi^{2}(7)=29.16$ \\
\hline Male & 54.3 & 53.7 & 57.6 & 63.2 & 55.2 & 54.6 & 54.2 & 50.2 & $p<0.001$ \\
\hline \multicolumn{10}{|l|}{ Age group } \\
\hline $18-24$ & 11.5 & 17.9 & 17.0 & 14.5 & 13.4 & 19.9 & 11.5 & 13.4 & $\chi^{2}(21)=167.42$ \\
\hline $25-39$ & 29.3 & 33.2 & 38.0 & 27.7 & 32.5 & 34.8 & 25.5 & 35.5 & $p<0.001$ \\
\hline $40-54$ & 34.7 & 35.0 & 30.0 & 36.0 & 36.2 & 25.8 & 33.2 & 30.4 & \\
\hline 55 years and older & 24.5 & 13.9 & 14.9 & 21.7 & 17.9 & 19.4 & 29.8 & 20.7 & \\
\hline \multicolumn{10}{|l|}{ Educational level } \\
\hline Low & 35.4 & 16.8 & 17.0 & 29.3 & 19.5 & 31.1 & 23.0 & 24.0 & $\chi^{2}(14)=452.03$ \\
\hline Moderate & 44.7 & 39.0 & 33.6 & 34.7 & 38.0 & 32.3 & 35.3 & 31.5 & $p<0.001$ \\
\hline High & 19.9 & 44.2 & 49.4 & 36.0 & 42.5 & 36.5 & 41.7 & 44.5 & \\
\hline \multicolumn{10}{|l|}{ Income level } \\
\hline Low & 24.9 & 27.2 & 23.9 & 24.5 & 21.8 & 37.6 & 38.1 & 28.6 & $\chi^{2}(21)=477.60$ \\
\hline Moderate & 23.0 & 30.0 & 26.5 & 24.1 & 28.8 & 20.8 & 28.2 & 31.4 & $\mathrm{p}<0.001$ \\
\hline High & 30.1 & 40.0 & 45.4 & 36.7 & 35.9 & 33.4 & 25.2 & 30.7 & \\
\hline No answer & 22.0 & 2.7 & 4.1 & 14.7 & 13.6 & 8.1 & 8.5 & 9.3 & \\
\hline \multicolumn{10}{|l|}{ Employment } \\
\hline Unemployed & 39.3 & 33.1 & 28.4 & 28.3 & 25.7 & 33.1 & 46.6 & 39.1 & $\chi^{2}(7)=124.48$ \\
\hline Employed & 60.7 & 66.9 & 71.6 & 71.7 & 74.3 & 66.9 & 53.6 & 60.9 & $p<0.001$ \\
\hline \multicolumn{10}{|l|}{ Smoking characteristics } \\
\hline \multicolumn{10}{|l|}{ Smoking status } \\
\hline Daily smoker & 92.7 & 92.0 & 90.7 & 92.3 & 90.7 & 89.6 & 93.3 & 95.8 & $\chi^{2}(7)=39.55$ \\
\hline Occasional smoker & 7.3 & 8.0 & 9.3 & 7.7 & 9.3 & 10.4 & 6.7 & 4.2 & $p<0.001$ \\
\hline \multicolumn{10}{|l|}{ Heaviness of smoking $\dagger$} \\
\hline $0-1$ & 28.4 & 44.5 & 48.2 & 43.2 & 37.7 & 30.4 & 23.0 & 23.7 & $\chi^{2}(14)=311.70$ \\
\hline $2-4$ & 63.7 & 52.1 & 48.3 & 51.4 & 56.9 & 61.2 & 63.7 & 68.4 & $p<0.001$ \\
\hline $5-6$ & 7.9 & 3.4 & 3.5 & 5.4 & 5.5 & 8.4 & 13.2 & 8.0 & \\
\hline \multicolumn{10}{|l|}{ Intention to quit } \\
\hline Not within 6 months & 78.5 & 62.8 & 61.3 & 77.4 & 73.3 & 64.6 & 58.4 & 73.1 & $\chi^{2}(7)=189.05$ \\
\hline Within 6 months & 21.5 & 37.2 & 38.7 & 22.6 & 26.7 & 35.4 & 41.6 & 26.9 & $p<0.001$ \\
\hline \multicolumn{10}{|c|}{ Smokes exclusively rolling tobacco } \\
\hline $\begin{array}{l}\text { Yes, exclusively rolling } \\
\text { tobacco }\end{array}$ & 32.1 & 13.1 & 11.3 & 10.0 & 13.9 & 4.3 & 17.0 & 27.5 & $\chi^{2}(7)=451.03$ \\
\hline $\begin{array}{l}\text { No, factory made } \\
\text { cigarettes or both }\end{array}$ & 67.9 & 86.9 & 88.7 & 90.0 & 86.1 & 95.7 & 83.0 & 72.5 & $p<0.001$ \\
\hline
\end{tabular}

state of Germany, and respondents living in the UK (excluding Scotland) were more likely to frequently buy cigarettes outside their country than respondents from The Netherlands. The Netherlands was chosen as the reference country because crossborder purchasing was lowest in this country.

\section{Cross-border cigarette purchasing in border regions}

As illustrated in figure 1, the highest rates of frequent cross-border purchasing were found in the French provinces Nord-Pasde-Calais, Lorraine, Alsace, Aquitaine and Languedoc-Roussillon, and in the German states of Brandenburg, Saxony and Saarland. These provinces/states border Belgium (Nord-Pas-de-Calais and Lorraine), Luxembourg (Lorraine and Saarland), Switzerland and Germany (Alsace), Spain (Aquitaine and Languedoc-Roussillon), Poland (Brandenburg and Saxony) and the Czech Republic
(Saxony). Please note that figure 1 provides merely an indication of regional variations as the number of respondents is low for some provinces/states (see footnotes of table 1). In other analyses, respondents from all border provinces/states were taken together per country which yielded a satisfactory number of respondents per category (see table 2).

An additional multinomial logistic regression analysis was performed on respondents from the above mentioned French provinces and German states with the highest rates of frequent cross-border cigarette purchasing $(\mathrm{n}=552$, not shown in tables). A notable difference with the correlates of cross-border purchasing among all respondents of the study was that higher income was not associated with frequent cross-border purchasing but it was associated with fewer reports of occasional cross-border purchasing. 
Table 3 Differences in cross-border cigarette purchasing between country/region, educational levels and income levels (\%)

\begin{tabular}{|c|c|c|c|c|}
\hline & $\begin{array}{l}\text { No cross-border } \\
\text { purchasing }\end{array}$ & $\begin{array}{l}\text { Occasional cross-border } \\
\text { purchasing }\end{array}$ & $\begin{array}{l}\text { Frequent cross-border } \\
\text { purchasing }\end{array}$ & $\begin{array}{l}\text { Test of differences in } \\
\text { cross-border purchasing }\end{array}$ \\
\hline \multicolumn{5}{|l|}{ Country and region } \\
\hline Netherlands & 82.7 & 14.9 & 2.4 & \multirow{8}{*}{$\begin{array}{l}\chi^{2}(14)=771.59 \\
p<0.001\end{array}$} \\
\hline Border provinces of France & 48.6 & 27.8 & 23.7 & \\
\hline Non-border provinces of France & 66.5 & 28.9 & 4.6 & \\
\hline Border states of Germany & 52.6 & 34.0 & 13.4 & \\
\hline Non-border states of Germany & 64.3 & 30.8 & 4.9 & \\
\hline Ireland & 73.5 & 23.4 & 3.1 & \\
\hline Scotland & 77.9 & 17.6 & 4.5 & \\
\hline UK (w/o Scotland) & 63.3 & 30.1 & 6.6 & \\
\hline \multicolumn{5}{|l|}{ Educational level } \\
\hline Low & 76.5 & 18.2 & 5.3 & \multirow{3}{*}{$\begin{array}{l}\chi^{2}(4)=130.19 \\
p<0.001\end{array}$} \\
\hline Moderate & 69.4 & 23.5 & 7.1 & \\
\hline High & 61.4 & 30.7 & 7.8 & \\
\hline \multicolumn{5}{|l|}{ Income level } \\
\hline Low & 75.7 & 18.5 & 5.8 & \multirow{4}{*}{$\begin{array}{l}\chi^{2}(6)=184.88 \\
p<0.001\end{array}$} \\
\hline Moderate & 69.0 & 23.6 & 7.4 & \\
\hline High & 59.2 & 32.4 & 8.4 & \\
\hline No answer & 75.7 & 19.7 & 4.5 & \\
\hline
\end{tabular}

\section{DISCUSSION}

This study showed that in most of the European countries studied, only a small minority of smokers reported frequent cross-border cigarette purchasing. The proportion was, however, higher in French and German provinces/states bordering countries with lower cigarette prices (ie, Belgium, Luxembourg, Switzerland, Spain, Poland and the Czech Republic), where 24\% of French smokers and 13\% of German smokers reported purchasing cigarettes frequently outside their country. In non-border regions of France and Germany, Ireland, the UK and The Netherlands, frequently purchasing cigarettes outside the country was reported by only $2-7 \%$ of smokers. Occasionally purchasing cigarettes outside the country was more commonly reported, but this might not always be indicative of tax avoidance. Smokers who occasionally purchased cigarettes outside the country did not pay significantly less on average for their cigarettes than smokers who never purchased outside the country, whereas smokers who frequently purchased outside the country did pay significantly less on average. Therefore, we suspect that smokers who cross the border frequently and buy cigarettes may do this intentionally to avoid taxes, whereas smokers who do this occasionally may be outside their country in the normal course of their activities, and could take advantage of such travelling by purchasing cheaper cigarettes.

Cross-border cigarette purchasing was more prevalent among smokers with higher education and income. This is a somewhat counterintuitive finding, and seems contradictory to earlier findings that low SES smokers use contraband cigarette purchasing as a strategy to deal with the increased cost of cigarettes. ${ }^{11} 26$ However, other studies have also shown that higher SES smokers are more likely to purchase cigarettes from low or untaxed sources than lower SES smokers. ${ }^{15-17}$ A possible explanation is that cross-border purchasing incurs travel costs, which smokers with lower education and income may not be able to pay up-front, ${ }^{16}$ while purchasing contraband cigarettes is often possible in the immediate social environment of low SES smokers. ${ }^{26}$ Additionally, the larger percentage of more highly educated and high-income smokers who occasionally purchase cigarettes abroad may reflect the fact that smokers with higher education and income levels travel abroad more often for vacations and work. ${ }^{27}$

\section{Limitations}

Because cross-sectional data were used for this study, no conclusions on causal links between predictor variables and crossborder cigarette purchasing could be drawn.

Fieldwork periods differed across countries, and the mode of interviewing was different for most of the ITC Netherlands sample. Also, educational levels and income levels were only partly comparable across countries because of differences in educational systems and differences in income variables. However, we explored different categorisations of educational levels and income levels and these yielded comparable results. Therefore, we do not think this has influenced our results.

We assumed that smokers who reported frequently purchasing cigarettes outside their country did this intentionally to avoid taxes. Alternatively, these smokers may routinely travel to other countries in the normal course of their activities, for example, because they work across the border. Another issue is that we were not able to distinguish between legal tax avoidance and illegal tax evasion, because we did not ascertain the quantities of cigarettes imported. Future research should therefore assess cross-border cigarette purchasing in more detail, including quantities of cigarettes bought.

Living close to an open border with a country with lower cigarette prices was operationalised as living in certain border provinces/states. This is a very rough measure that is affected by the shape and size of the province/state. It would have been better to know the actual distance between respondents' homes and the country border. Also, because the number of respondents was low for some provinces/states, we could only provide an indication of regional variations.

\section{Future research}

In this study, respondents were only asked whether they bought cigarettes outside their country and how often they did this. In 
Table 4 Multinomial logistic regression analysis of correlates of occasional and frequent categories of cross-border cigarette purchasing-no cross-border purchasing is reference category $(n=7752)$

\begin{tabular}{|c|c|c|}
\hline & $\begin{array}{l}\text { Occasional vs no cross-border } \\
\text { purchasing } \mathrm{OR}(95 \% \mathrm{Cl})\end{array}$ & $\begin{array}{l}\text { Frequent vs no cross-border } \\
\text { purchasing OR }(95 \% \mathrm{Cl})\end{array}$ \\
\hline \multicolumn{3}{|l|}{ Gender } \\
\hline Female & 1.00 & 1.00 \\
\hline Male & $1.10(0.98$ to 1.23$)$ & $1.07(0.88$ to 1.30$)$ \\
\hline \multicolumn{3}{|l|}{ Age group } \\
\hline $18-24$ & 1.00 & 1.00 \\
\hline $25-39$ & $0.74(0.61 \text { to } 0.90)^{\star *}$ & $0.71(0.51 \text { to } 0.98)^{*}$ \\
\hline $40-54$ & $0.78(0.66 \text { to } 0.93)^{* *}$ & $0.58(0.43 \text { to } 0.77)^{* * *}$ \\
\hline 55 years and older & $0.75(0.64 \text { to } 0.89)^{* * *}$ & 0.77 (0.58 to 1.01$)$ \\
\hline \multicolumn{3}{|l|}{ Educational level } \\
\hline Low & 1.00 & 1.00 \\
\hline Moderate & $1.23(1.06 \text { to } 1.43)^{* *}$ & $1.21(0.93$ to 1.57$)$ \\
\hline High & $1.51(1.30 \text { to } 1.76)^{* * *}$ & $1.36(1.05 \text { to } 1.78)^{*}$ \\
\hline \multicolumn{3}{|l|}{ Income level } \\
\hline Low & 1.00 & 1.00 \\
\hline Moderate & $1.25(1.07 \text { to } 1.47)^{* *}$ & $1.33(1.02 \text { to } 1.73)^{*}$ \\
\hline High & $1.87(1.61 \text { to } 2.17)^{* * *}$ & $1.76(1.36 \text { to } 2.27)^{* * *}$ \\
\hline No answer & $1.16(0.94$ to 1.43$)$ & $1.08(0.73$ to 1.60$)$ \\
\hline \multicolumn{3}{|l|}{ Employment } \\
\hline Unemployed & 1.00 & 1.00 \\
\hline Employed & $1.25(1.09 \text { to } 1.42)^{* * *}$ & $1.19(0.95$ to 1.49$)$ \\
\hline \multicolumn{3}{|l|}{ Smoking status } \\
\hline Daily smoker & 1.00 & 1.00 \\
\hline Occasional smoker & $0.68(0.54 \text { to } 0.85)^{* * *}$ & $0.40(0.24 \text { to } 0.68)^{* * *}$ \\
\hline Heaviness of smoking & $0.99(0.95$ to 1.03$)$ & $1.11(1.04 \text { to } 1.19)^{* *}$ \\
\hline \multicolumn{3}{|l|}{ Intention to quit } \\
\hline Not within 6 months & 1.00 & 1.00 \\
\hline Within 6 months & 0.94 (0.84 to 1.06$)$ & $0.62(0.50 \text { to } 0.78)^{* * *}$ \\
\hline \multicolumn{3}{|l|}{ Smokes exclusively rolling tobacco } \\
\hline Yes, exclusively rolling tobacco & 1.00 & 1.00 \\
\hline No, factory made cigarettes or both & $1.31(1.13 \text { to } 1.53)^{* * *}$ & 0.81 (0.64 to 1.03$)$ \\
\hline \multicolumn{3}{|l|}{ Country and region } \\
\hline The Netherlands & 1.00 & 1.00 \\
\hline Border provinces of France & $1.83(1.34 \text { to } 2.48)^{\star * *}$ & $12.42(6.82 \text { to } 22.59)^{* * *}$ \\
\hline Non-border provinces of France & $1.30(0.96$ to 1.76$)$ & $1.66(0.86$ to 3.21$)$ \\
\hline Border states of Germany & $2.13(1.53 \text { to } 2.96)^{* * *}$ & $6.42(3.40 \text { to } 12.10)^{* * *}$ \\
\hline Non-border states of Germany & $1.56(1.16 \text { to } 2.08)^{* *}$ & $1.77(0.94$ to 3.36$)$ \\
\hline Ireland & 1.04 (0.75 to 1.44$)$ & $1.05(0.50$ to 2.21$)$ \\
\hline Scotland & $0.85(0.60$ to 1.21$)$ & $1.54(0.76$ to 3.14$)$ \\
\hline UK (w/o Scotland) & $1.66(1.25 \text { to } 2.20)^{* * *}$ & $2.34(1.28 \text { to } 4.29)^{* *}$ \\
\hline \multicolumn{3}{|l|}{ Interviewing mode } \\
\hline Telephone & 1.00 & 1.00 \\
\hline Web & $0.61(0.46 \text { to } 0.82)^{* * *}$ & $0.60(0.31$ to 1.16$)$ \\
\hline
\end{tabular}

future research, respondents should be interviewed in more detail about their cross-border shopping behaviours. Important questions are: why did they buy cigarettes abroad? Was buying cigarettes the goal of travelling to another country or were they abroad for other purposes such as vacation or work? In which country did they buy cigarettes? How many cigarettes did they buy, and how often? Did a friend or acquaintance buy cigarettes abroad for them or did they buy cigarettes for others? The answers to these questions could give more insight into the actual reasons behind socioeconomic and country differences in cross-border cigarette purchasing.

\section{Policy recommendations}

Tobacco tax avoidance strategies, such as cross-border cigarette purchasing, may attenuate the impact of tax increases on tobacco consumption. ${ }^{4}$ We found in our study that cross-border purchasing was most common in regions bordering countries that have considerably lower cigarette prices. Therefore, increasing tobacco taxes in countries with lower cigarette prices could help to limit crossborder shopping and help motivate smokers from both these countries and from their neighbouring countries to quit smoking.

The EU can also help to limit cross-border cigarette purchasing. ${ }^{7} 28$ The EU is urged to implement policy measures to 
reduce price differences between EU countries, ${ }^{28}$ and also to reduce to 200 per person the number of cigarettes that can be legally imported for personal consumption, or 250 grams of rolling tobacco. ${ }^{7}$ These measures make it less lucrative to cross the border for cheaper cigarettes.

\section{CONCLUSIONS}

Cross-border cigarette purchasing was relatively common in French and German provinces/states that border countries with considerably lower cigarette prices (eg, Luxembourg, Spain and Poland). Twenty-four percent of smokers from these French provinces and $13 \%$ of smokers from these German states reported frequently purchasing cigarettes outside their country. In nonborder regions of France and Germany and in Ireland, the UK and The Netherlands, frequently purchasing cigarettes outside the country was reported by only $2-7 \%$ of smokers. Cross-border cigarette purchasing is more prevalent among smokers with higher education and income. Increasing tobacco taxes in countries with lower cigarette prices, and reducing the number of cigarettes that can be legally imported across borders could help to limit cross-border purchasing by smokers from countries with higher cigarette prices.

\section{What this paper adds}

- Cross-border cigarette purchasing was most common in French and German provinces/states bordering countries such as Luxembourg, Spain and Poland where cigarette prices are considerably lower.

- In non-border regions of France and Germany, Ireland, the UK and The Netherlands, few smokers reported crossing the border frequently to buy cigarettes.

- Cross-border cigarette purchasing was more prevalent among smokers with higher education and income.

\author{
Author affiliations \\ ${ }^{1}$ Department of Health Promotion, Maastricht University (CAPHRI), Maastricht, \\ The Netherlands \\ ${ }^{2}$ STIVORO Dutch Expert Centre on Tobacco Control, The Haque, The Netherlands \\ ${ }^{3}$ Department of Communication, University of Amsterdam (ASCoR), Amsterdam, \\ The Netherlands \\ ${ }^{4}$ Department of Public Health and Primary Care, Trinity College Dublin, Tallaght, Ireland \\ ${ }^{5}$ Division of Clinical Epidemiology and Aging Research, German Cancer Research Center \\ (DKFZ), Heidelberg, Germany \\ ${ }^{6}$ UK Centre for Tobacco Control Studies, King's College London, London, UK \\ ${ }^{7}$ French Institute for Health Promotion and Health Education (INPES), Saint-Denis, France \\ ${ }^{8}$ Cermes3 - Cesames team (Research Centre Medicine, Sciences, Health, Mental Health, \\ Health Policy), CNRS UMR 8211, Inserm U988, University of Paris Descartes, Sorbonne \\ Paris Cité, EHESS, Paris, France \\ ${ }^{9}$ Department of Health Promotion, Social and Behavioral Health, College of Public \\ Health, University of Nebraska Medical Center, Omaha, Nebraska, USA \\ ${ }^{10}$ Foundation Against Cancer, Association of European Cancer Leagues, Brussels, Belgium \\ ${ }^{11}$ Department of Psychology, School of Public Health and Health Systems, University of \\ Waterloo, Waterloo, Ontario, Canada \\ ${ }^{12}$ Ontario Institute for Cancer Research, Toronto, Ontario, Canada
}

Acknowledgements Several members of the ITC Project team at the University of Waterloo have assisted in all stages of conducting the ITC Europe surveys, which we gratefully acknowledge. In particular, we thank Lorraine Craig, Project Manager of ITC Europe. We also thank Anton Kunst of the Academic Medical Centre of the University of Amsterdam and coordinator of the SILNE Project for advising on the statistical analyses and the writing of the manuscript. This paper is a deliverable within the SILNE Project 'Tackling socioeconomic inequalities in smoking: Learning from natural experiments by time trend analyses and cross-national comparisons'.
Contributors GEN conducted the statistical analyses and drafted the manuscript. She is the guarantor of the paper. MCW and BvdP contributed to the design of the study and to the statistical analyses. All authors contributed to the interpretation of the data and to the writing of the manuscript. All authors revised the manuscript critically for important intellectual content and read and approved the final manuscript.

Funding The ITC Europe surveys were supported by grants from the French Institute for Health Promotion and Health Education (INPES), the French National Cancer Institute (INCa) (France wave 1), The Netherlands Organisation for Health Research and Development (ZonMw) (The Netherlands wave 1), German Federal Ministry of Health, Dieter Mennekes-Umweltstiftung and Germany Cancer Research Center (DKFZ) (Germany wave 1), US National Cancer Institute R01 CA090955 (Ireland wave 3), Cancer Research UK C312/A6465 (UK wave 5), NHS Health Scotland RE065 and Flight Attendants' Medical Research Institute (FAMRI) (Scotland wave 3). The ITC Project is supported by the US National Cancer Institute (P50 CA111236, R01 CA100362, and P01 CA138389) and the Canadian Institutes of Health Research $(57897,79551,115016)$. Geoffrey Fong is supported by a Senior Investigator Award from the Ontario Institute for Cancer Research and a Prevention Scientist Award from the Canadian Cancer Society Research Institute. The SILNE Project is funded by the European Commission through FP7

HEALTH-F3-2011-278273.

\section{Competing interests None.}

Ethics approval Office of Research Ethics of the University of Waterloo.

Provenance and peer review Not commissioned; externally peer reviewed.

\section{REFERENCES}

1 World Health Organization. WHO technical manual on tobacco tax administration. Geneva: World Health Organization, 2010

2 Levy DT, Hyland A, Higbee C, et al. The role of public policies in reducing smoking prevalence in California: results from the California tobacco policy simulation model. Health Policy 2007;82:153-66.

3 Fong GT. Surveys of the International Tobacco Control Policy Evaluation Project (ITC Project): aspects of creating an ITC Survey. Measuring the Effectiveness of Tobacco Control Workshop. Bethesda, MD, USA, 2006.

4 Chaloupka FJ, Straif K, Leon ME. Effectiveness of tax and price policies in tobacco control. Tob Control 2011;20:235-8.

5 Merriman D. Cigarette smuggling does not reduce the public health benefits of cigarette taxes. Appl Econ Lett 2002;9:493-6.

6 Joossens L, Raw M. Smuggling and cross border shopping of tobacco in Europe. BMJ 1995:310:1393-7.

7 Joossens L, Raw M. Progress in tobacco control in 30 European countries, 2005 to 2007. Bern: Swiss Cancer League, 2007.

8 Bogdanovica I, Murray R, McNeill A, et al. Cigarette price, affordability and smoking prevalence in the European Union. Addiction 2012:107:188-96.

9 Lakhdar CB. Quantitative and qualitative estimates of cross-border tobacco shopping and tobacco smuggling in France. Tob Control 2008;17:12-6.

10 Lakhdar CB, Lermenier A, Vaillant NG. Estimation des achats transfrontaliers de cigarettes 2004-2007. Saint-Denis-La-Plaine: Observatoire Francais des Drogues et des Toxicomanies 2011.

11 Joossens L, Raw M. From cigarette smuggling to illicit tobacco trade. Tob Control 2012:21:230-4.

12 European Commission. Survey on tobacco: Analytical report. Hungary: The Gallup Organisation, 2009, Eurobarometer \#253.

13 Leal A, López-Laborda J, Rodrigo F. Cross-border shopping: a survey. Int Adv Econ Res 2010;16:135-48.

14 Hanewinkel $R$, Isensee $B$. Access to cheaper cross-border cigarettes may decrease smoking cessation intentions in Germany. Tob Control 2007;16:70-1.

15 Hyland A, Laux FL, Higbee C, et al. Cigarette purchase patterns in four countries and the relationship with cessation: findings from the International Tobacco Control (ITC) Four Country Survey. Tob Control 2006;15(Suppl 3):59-64.

16 Licht AS, Hyland AJ, O'Connor RJ, et al. Socio-economic variation in price minimizing behaviors: findings from the International Tobacco Control (ITC) Four Country Survey. Int J Environ Res Public Health 2011;8:234-52.

17 Peretti-Watel P, L'Haridon O, Seror V. Responses to increasing cigarette prices in France: how did persistent smokers react? Health Policy 2012;106:169-76.

18 DeCicca P, Kenkel DS, Liu F. Excise tax avoidance: the case of state cigarette taxes. NBER working paper series. Cambridge, MA: National Bureau of Economic Research, 2010.

19 Pesko MF, Kruger J, Hyland A. Cigarette price minimization strategies used by adults. Am J Public Health 2012;102:e19-21.

20 The American Association for Public Opinion Research. Standard definitions: Final dispositions of case codes and outcome rates for surveys. Deerfield, Illinois: AAPOR, 2009. 
21 Nagelhout GE, Willemsen MC, Thompson ME, et al. Is web interviewing a good alternative to telephone interviewing? Findings from the International Tobacco Control (ITC) Netherlands Survey. BMC Public Health 2010;10:351.

22 Fong GT, Cummings M, Borland R, et al. The conceptual framework of the International Tobacco Control (ITC) Policy Evaluation Project. Tob Control 2006;15 (Suppl 3):3-11.

23 European Commission. Excise duty tables. Tobacco. Brussels: Directorate General Taxation and Customs Union Tax Policy, 2006-2008.

24 Schaap MM, Kunst AE. Monitoring of socio-economic inequalities in smoking: learning from the experiences of recent scientific studies. Public Health 2009;123:103-9.
25 Heatherton TF, Kozlowski LT, Frecker RC, et al. Measuring the heaviness of smoking: using self-reported time to the first cigarette of the day and number of cigarettes smoked per day. Br J Addict 1989;84:791-800.

26 Wiltshire S, Bancroft A, Amos A, et al. They're doing people a service' - qualitative study of smoking, smuggling, and social deprivation. BMJ 2001;323:203-7.

27 Gump BB, Matthews KA. Are vacations good for your health? The 9-year mortality experience after the multiple risk factor intervention trial. Psychosom Mede 2000;62:608-12.

28 European Commission. Tobacco or health in the European Union. Past, present and future. Luxembourg: Office for Official Publications of the European Communities, 2004. 